\title{
Beyond the Nation-state Narrative: An Empirical Inquiry into the Cross-Country and Cross-Income-Group Carbon Consumption Patterns - Corrigendum
}

Ying Chen, (D) and Güney Işıkara

https://doi.org/10.1017/S1355770X21000036, Published by Cambridge University Press, 12 April 2021

Keywords: degrowth; environmental justice; global warming; growth; inequality; mitigation; corrigendum

When originally published, the article omitted to include equal accreditation to both authors. The article has now been updated to include this.

The authors apologies for this error.

\section{Reference}

Chen Y and Ișıkara G (2021) Beyond the nation-state narrative: An empirical inquiry into the cross-country and cross-income-group carbon consumption patterns. Environment and Development Economics, 1-19. doi:10.1017/S1355770X21000036

Cite this article: Chen Y, Işıkara G (2023). Beyond the Nation-state Narrative: An Empirical Inquiry into the Cross-Country and Cross-Income-Group Carbon Consumption Patterns - Corrigendum. Environment and Development Economics 28, 210. https://doi.org/10.1017/S1355770X21000164 